\title{
Implications and Conceptual Characteristics of the December 19, 1991 Directive on the Annual Accounts and Consolidated Accounts of Insurance Undertakings
}

\author{
by Hans-Joachim Welzel*
}

\section{Legal principles}

On the 19th of December, 1991 - after 12 years of consultation(!) - the Council of Ministers of the European Community (EC) approved the Council Directive on The Annual Accounts and Consolidated Accounts of Insurance Undertakings (Official Journal [OJ] No. L 374 dated 19.12.91 page 7 onwards). With the exception of the still outstanding EC Directive on Accounting Standards for Foreign Branches of Insurance Undertakings, this Insurance Accounts Directive (IAD) should be the final of a series of EC Directives harmonizing accounting standards for companies within the EC.

The legal basis for harmonization is Art. 54, Paragraph 3, g of the Treaty of Rome establishing the European Economic Community (signed March 25, 1957). It is proposed that the protection provisions with respect to companies which have been prescribed in the Member States in accordance with Article 58, Paragraph 2 (in the interests of shareholders as well as third parties) should, as far as necessary, be put on a par with one another.

The necessity for harmonization arises first of all from the special need for protection of shareholders and creditors of such undertakings which offer as security to third parties only the undertaking's assets. Harmonization is also necessary for competitive reasons, since companies which compete with each other in a common market should have to meet at least the same minimum reporting requirements.

2. Placing the Insurance Accounts Directive into the context of company and regulatory law

\subsection{The company-law environment}

On this basis, a number of EC Company-law Directives were published, of which the Fourth Directive - the so-called Accounts Directive - of July 25, 1978, and the Seventh Directive of June 13, 1983 - one so-called Consolidated Accounts Directive - are especially important for our purposes. (On December 19, 1985 both directives were transformed, together with the Eighth EC Business-Law Directive - the so-called Auditor Directive, dated April 10, 1984 - into German Law by the "Bilanzrichtlinien-Gesetz"). In addition to

\footnotetext{
* Vice Secretary General of the Geneva Association, Bonn.
} 
these, the Banking Accounts Directive was published on December 8, 1986 (OJ. No. L 372 dated 31.12.1986, p. 1 and following). The Banking Directive, as with the IAD, does not setout regulations independent of the Fourth and Seventh EC Directives, but instead, both the Banking Directive and the Insurance Directive have been created - corresponding to the coordination of accounting regulations foreseen in Article 1, Paragraph 2 of the Fourth Directive and Article 40, Paragraph 1 of the Seventh Directive - and deal, as a matter of principle, solely with issues specific to accounting for insurance undertakings, banks and other financial institutions. They therefore only regulate deviations from the Fourth and Seventh EC Directives, with reference to the preambles (detailing matters to be taken into consideration) of the Banking and Insurance Directives.

It is common in both Directives that they, as opposed to the other Accounting Directives, based on Article 54, Paragraph 3, g of the Treaty of Rome, are independent of the legal form of the undertaking and therefore do not only apply to companies limited by shares. This arises from the special "obligation of trust" which insurance companies have with respect to their policyholders and the public and the specific need for trust in the case of credit institutions.

The Insurance Accounts Directive should, though, also be looked at together with the other insurance-specific Directives, especially the Third Property and Casualty and Life Coordination Directives. The Property and Casualty Directive has already been approved (Directive dated June 18, 1992; OJ. No. L228 dated 11.8. 1992, p. 1) and the Life Directive is currently in the form of an amended proposal on which a common position has been reached. (Proposal dated June 22, 1992, OJ. No. C 196 dated 3.8.1992, p. 9), subsequently adopted November 10, 1992.

\subsection{The regulatory environment}

The above-mentioned independence from legal form is the result of industry-specific, regulatory inspired considerations. As a matter of fact, the IAD has a key position with regard to the planned financial regulation in the common market in accordance with the third generation of Directives. The aim of the third generation of Directives is the bringing together of regulatory systems.

The Third Life Coordination Directive will provide the basis for determination of the technical provisions. The Third Property and Casualty Coordination Directive refers to the determination of technical provisions according to the specifications of the Insurance Accounts Directive. It also regulates the establishment of the equalization provision for credit insurance. Through this connection, the accounting and valuation specifications of the Insurance Accounts Directive have greater significance for two important regulatory safety parameters : that the assets held to cover insurance liabilities should be "qualified" (appropriate) assets, and that solvency should be calculated based on the valuation of specific assets and liabilities.

Lastly, it is also important to draw attention to the tax consequences of the Insurance Accounts Directive from the point of view of the relationship between the statutory balance sheet and the tax balance sheet (as exists in some countries - for example Germany).

\section{Implementation periods}

How do things look with the deadlines for implementing the Directive and its coming into effect? The Directive must be transformed into the national laws of Member States before January 1, 1994, (in accordance with Article 70, Paragraph 1). The Member States 
can then demand application of the Directive for the financial statements relating to the business years which begin on January 1, 1995 (or during the following calendar year).

The national legislators have, if they specifically exercise this option, the possibility of allowing insurance undertakings a period of one year in which to amend their accounting systems to comply with the new accounting standards. Article 46, Paragraph 3 of the IAD provides an additional transitional period with regard to the duty of disclosing the current value of investments which have been included in the accounts at purchase price: Land and buildings for five years from January 1, 1994, and other investments three years from January 1,1994 . The transitional periods seem tight in comparison to the implementation periods foreseen in earlier Directives dealing with accounting issues. (The Fourth EC Directive had, as stated in Article 54, Paragraph 2, a transitional period of 18 months. In Article 49 of the Seventh Directive - concerning consolidated accounts - and Article 59 of the Banking Accounts Directive, a transitional period of 2 years was provided for).

\section{Points worth noting on the set-up of the Insurance Accounts Directive}

\subsection{Coexistence of systems}

Purists may be unsatisfied by the Insurance Accounts Directive because, more so than in previous EC accounting Directives, this one has been influenced by different accounting philosophies: most importantly, continental accounting interpretation on the one hand, and anglo-saxon accounting interpretation on the other hand have been equally valued by the Directive. Both systems are in large part characterized by elements of the (in German literature) so-called static and dynamic accounting approaches which have dominated theoretical discussions in Germany up to recent times (and especially recently in connection with the coming into force of the General Accounting Directives by the "BilanzrichtlinienGesetz" in 1985).

Arising from the desire to protect creditors, the main goal of the static accounts approach is to provide a "correct" presentation of assets. This corresponds with the current value valuation method, however, in the interests of creditor protection also with regard to prudence and net realizable value principles. Other characteristics are a distinct presentation of accounts ordered according to liquidity age (long/short term) and realizibility. A special problem exists with the time value principle in that it gives rise to unrealized profits which, in the interest of maintenance of net asset value and creditor protection, one should try to avoid paying tax on or paying out as dividends. The layout of the profit and loss account is of relatively less importance.

The dynamic accounting approach has as primary goal, in contrast, the presentation of "orderly" periodic results as an indicator of the economic performance of the undertaking. Accordingly, the result for the year (the result for a particular period) will be analyzed into ordinary and extraordinary elements (presentation of the sources of the result). This result-oriented approach corresponds to the valuation on the basis of expenditure and income, i.e. costs and revenue (historical cost principle; accruals concept). Accordingly, the balance sheet then becomes one large, transitory account, considered on the basis of the accruals concept. Unrealized profits will not, in principle, arise; unrealized losses are a result of the overriding prudence principle, which is foreign to the system. (General idea of creditor-protection from statutory law!). 
Both accounting approaches are combined in the Fourth Directive (the General Accounts Directive of July 25, 1978). This is very clearly stated as a general principle in Article 2, Paragraph 3:

"The annual accounts shall give a true and fair view of the company's assets, liabilities, financial position and profit or loss".

A criterion of the "static" approach is, for example, the duty to report the term with respect to debtors and creditors (Articles 9 and 43, Paragraph 1, No. 6).

In my opinion, characteristics of the "dynamic" approach are, for example, the accruals concept and the duty to report non-typical factors affecting the result (Article 29, Paragraph 2).

In the Fourth Directive, in the area of valuation, the historical cost principle clearly has the priority. The (restricted) possibilities to deviate from this basic principle of valuation, namely those along the lines of Article 33, are open to revision.

It remains to be seen in later phases of harmonization (for example what is currently taking place under the OECD framework) in which direction the pendulum will swing with respect to the accounting.

The Insurance Account Directive is distinguished by an especially high number of Member State options. This is particularly remarkable when one considers the introductory terms of reference of the Directive, under which it was supposed to set up no new rules not found in the Fourth and Seventh Directives, but rather to only deal with issues specific to insurance accounting. We count over 160 Member State options (with various levels of emphasis on the prudence principle in the area of valuation). The numerous option possibilities, of which many lead into still more option possibilities for insurance undertakings themselves, not only exist for the area of valuation but also for the more formal area of accounting, i.e., presentation in the financial statements.

Accordingly, the IAD is marked by two main conceptual influences:

- The connection with the principles of the Fourth and Seventh EC Directives - as long as the provisions of these do not contradict the unique characteristics of insurance business which require different regulations,

- A comparatively large field of choice in the area of insurance specific regulations; whereby, however, by specific supplementary disclosure in the financial statements the comparability of the different valuation and presentation options should be ensured to a greater extent. (Some examples of this will be given later.).

\subsubsection{Pluralismo of valuation-methods}

Most spectacular evidence for the above intended from the outset, is the egality of both the purchase cost and current value methods of valuation (Article 46, Paragraph 1). Valuation using current value can be either permitted or required by the Member States for all investments or for individual sub-items under balance sheet, item $\mathrm{C}$ investments. This does not, however, apply to "investments for the benefit of Life-assurance policyholders who bear the investment risk" (Asset item D). This means that investments held to cover liabilities arising from unit-linked business - comparatively large amounts of which are written in the UK - must be valued at current value. 
Article 55 permits debt securities and other fixed interest securities to be valued in a special way: The Member States can require or permit that these securities be shown in the balance sheet at the amount repayable at maturity and that the difference between this value and the respective purchase price be amortized over the period remaining until maturity.

This method, which is also found in the Banking Accounts Directive, is clearly intended to ensure, in the interest of comparability between accounting periods, an even recognization of investment income. The same consideration is of value in my opinion for other fixedinterest investments with premiums/discounts such as mortgages and loans against promissory notes.

However, as an important exception, the revaluation in the sense of Article 33, Paragraph 1, (c) of the Fourth Directive (compared with Article 44, 50 IAD) broadens significantly the number of methods which may be used to value investments, but without requiring that the comparability with other valuation methods be disclosed in the notes to the accounts. This must still be reviewed.

The acceptability of various valuation methods is further reflected in the important Member State options:

- Article 18: Deferral of acquisition costs through inclusion as an asset or by deduction from technical provisions (provision for unearned premiums, Life assurance provision) or their immediate write-off as an expense.

- Article 51: Principle of valuing securities at the lower cost or current value.

- Article 60: Discounting of the claims provision for provisions with an average date of settlement of over four years.

- Article 62: "Pending further coordination, those Member States which require the constitution of equalization provisions shall prescribe the valuation rules to be applied to them."

The scope of options might include:

- On the one hand, current values with deferred acquisition costs and discounted claims provision ("optimistic" model),

- On the other hand, valuation by the purchase cost principle without deferred acquisition costs and discounted claims provision ("pessimistic" model).

In reality, however, the EC Member States will probably use more of a mixture of methods somewhere between these extreme examples, which indeed do not represent the whole scope of possible variations.

The difference between these different "optimistic/pessimistic" models relates to timing differences with respect to the impact on the result, i.e. the presentation of profit. Apart from the interest and tax implications, the end effect is the same.

\subsubsection{Flexibility in accounts presentation}

A similar flexibility is found concerning the area of presentation, i.e. the "Layout". The deferral of acquisition costs can result in capitalization or deduction from unearned premiums or - in Life assurance - from the Life assurance provision (Article 18, Paragraph 2). 
So-called subrogation debtors can be capitalized, instead of being deducted from claims provision - according to a Member State option (Article 60, Paragraph 1).

Instead of deducting the reinsurancee proportion from technical provisions, these amounts may be shown as assets (Article 24, Paragraph 3).

A certain amount of choice also exists in the presentation of the result.

The division between insurance technical and non-technical accounts can be changed through Member State options. The "German model" is the basis for the presentation of the income and expenses with regard to investments, i.e. all primary incomes and expenses with respect to life assurance should be included in the insurance technical account, and non-life insurance and reinsurance in the non-technical account. According to Article 43, Member States may lay down the procedures for and the amounts of transfers of "allocated investment return" from one part of the profit and loss account to another. As different choices will be made, the technical insurance results of the undertakings in the various Member States will vary greatly, although recognizably.

Extremely complicated, and - in my opinion - questionable from several angles is the treatment of unrealized profit, which results from the current method of valuation of investments, in accordance with Article 46, Paragraph 1, and Articles 48 and 49 of the IAD and the revaluation method found in Article 33, Paragraph 1, (c) of the Fourth Directive.

With regard to unrealized gains and losses resulting from the valuation at the current value, art. 44 of the Insurance Accounts Directive states:

(1) In life-assurance business Member States may permit the disclosure in full or in part in items II (3) and (10) in the profit and loss account (Unrealized gains on investments/ Unrealized losses on investments) of variations in the difference between:

- The valuation of investments at their current value or by means of one of the methods referred to in Article 33 (Paragraph 1!) of Directive 78/660/EEC, and

- Their valuation at purchase price.

In any event, Member States shall require that the amounts referred to in the first paragraph be disclosed in the aforementioned items where they relate to investments shown as assets under $\mathbf{D}$.

(2) As for non-life insurance, Member States which require or permit the valuation of the investments shown as assets under $\mathrm{C}$ at their current value may permit the disclosure in full or in part as unrealized gains/losses in a (special) item III ( $3 a)$ and in an item III (5a) in the profit and loss account of the variation in the difference between the valuation of those investments at their current value and their valuation at purchase price.

According to these provisions, the disclosure under the items "Unrealized gains on investments" or "Unrealized losses on investments" is only compulsory with regard to unitlinked life assurance; in any other cases it is subject to a member state option.

What is to happen if a member state does not permit the disclosure in the profit and loss account? In this case, the system according to art. 33 of the Fourth Directive would apply, i.e. formation of a revaluation reserve with the corresponding options or obligations (art. 47 of the Insurance Accounts Directive), possibly without any effect on the profit and loss account. 
If a revaluation of investments according to art. 33, para. 1, lit. c of the Fourth Directive is made, in my opinion, the legal provisions which apply are those of the Fourth Directive, unless it is made use of the option existing for life assurance according to art. 44, para. 1 ; these provisions, however, do not mention the disclosure of the unrealized gains or losses in the profit and loss account. One might consider a neutralization outside the profit and loss account through the formation of a revaluation reserve, which, again, may be transformed into subscribed capital, i.e. own funds (!).

An exception from the neutralization of gains resulting from revaluations, which is required by art. 33 of the Fourth Directive, is permitted by art. 44 for life assurance. According to this, member states may permit the disclosure as unrealized gains or losses of the differences in value resulting from the application of one of the valuation methods of art. 33, para. 1 .

The extension of the regulation on neutralization of article 33 , para. 2 of the Fourth Directive to gains resulting from revaluation with regard to all investments - according to art. 33 , para. 1, clause 1 , lit. c a revaluation is only admissible with regard to tangible and financial assets - and the application of this procedure to the valuation at the current value, which is also applicable to all investments, is questionable because of the transformation of volatile assets into subscribed capital, which would be possible in this case.

However, in my opinion, it is even more questionable that the system obviously makes it also possible to distribute unrealized gains valuated at the current value, with a delay for the case that, according to art. 22 , they are shown under the fund for future appropriations, "where a Member State permits an undertaking's balance sheet to include funds, the allocation of which either to policyholders or to shareholders has not been determined by the close of the financial year"; however, in practice, this apparently concerns only life assurance.

\subsection{Comparability as an aim}

The writers of the Directive were certainly aware of the lack of homogeneity in the systems permitted by the Directive. As referred to in the opening preamble containing points for consideration, they sought a solution to the problem with respect to the comparability of the different methods by requiring additional disclosures in the notes on the accounts. These requirements would still be subject to the "materiality" concept. This method of compensation using supplementary information affects principally:

In the area of valuation:

- For unrealized profit and loss arising from current value method, Article 44 of the IAD states:

(1) In Life-assurance business Member States may permit that variations in the difference between:

- The valuation of investments at their current value or by means of one of the methods referred to in Article 33 (1) of the Fourth Directive and

- Their valuation at purchase price are disclosed in full or in part under items II (3) and (10) ("unrealized gains on investments/unrealized losses on investments") in the profit and loss account. 
In any event, Member States shall require that the amounts referred to in the first paragraph be disclosed in the aforementioned items where they relate to investments shown as assets under D.

(2) In non-life insurance, Member States which require or permit the valuation of the investments shown as assets under $\mathrm{C}$ at their current value may permit the disclosure in full or in part in an item III ( $3 a)$ and in an item III (5a) in the profit and loss account of the variation in the difference between the valuation of those investments at their current value and their valuation at purchase price.

Therefore it is only mandatory in the case of unit-linked life assurance to make disclosure under "unrealized gains on investments" and "unrealized losses on investments". In other cases it is dependent on a Member State option. What happens when a Member State neither requires nor permits the disclosure in the profit and loss account? In this case the method set out in Article 33 of the Fourth Directive applies, i.e. the setting up of a revaluation reserve with the respective possibilities and conditions (Art. 47 IAD) but possibly without impact on the profit and loss account.

If a revaluation takes place in accordance with Article 33, Paragraph 1, (c) of the Fourth Directive, then - in my opinion - the Fourth Directive applies. Here, however, nothing is said with regard to the disclosure of unrealized profit in the profit and loss account. A reserve accounting outside the profit and loss account by way of a revaluation reserve, that can be transferred into subscribed capital, comes into consideration.

A similar treatment of the unrealized profits from current valuation in accordance with the IAD and revaluation in the sense of Article 33 of the Fourth Directive seems from consideration to be plausible. (The transfer of unrealized profits into capital!).

It seems even more plausible to me, however, that with this system a clear possibility exists for unrealized profits resulting from valuation at current value also to be paid out as dividends in so far as they are not (in accordance with Article 22) transferred to the "fund for future appropriations", "where a Member State permits an undertaking's balance sheet to include funds the allocation of which either to policyholders or to shareholders has not been determined by the close of the financial year". This seems, however, to really only affect life assurance.

- The respective, complementary valuations at purchase cost or current value (Article 46, Paragraphs 3 and 4) must be disclosed in the notes on the accounts. The revaluation loophole from Article 33 of the Fourth Directive was closed up out of necessity by the following Protocol:

"The Council and Commission clarify that Article 46, Paragraph 3 is also to the effect that the current value should also be shown in the notes on the accounts when the investments are valued in the balance sheet according to one of the principles of Article 33, Paragraph 1 of the Fourth Directive."

- Disclosure in the notes on the accounts of deferred acquisition costs deducted from unearned premiums and deducted from the life-assurance provision (Zillmerization) (Article 18, Paragraph 2).

- Disclosure in the notes on the accounts of the effect of discounting on the claims provision (Article 60, Paragraph 1, g.v.). 
In the area of presentation:

- Separate disclosure of the provision for unexpired risks in the balance sheet or the notes on the accounts when it is reported under unearned premiums or other technical provisions in cases where it is material. (Article 26).

- Disclosure of the reinsurance proportion of technical provisions shown net in the balance sheet.

- Disclosure in the notes on the accounts of the recoverable amounts arising out of subrogation or salvage deducted from the provision for claims outstanding, when such amounts are material. (Article 60, Paragraph 1,d).

- Disclosure should also be made in the notes on the accounts when equalization provisions have been created without any legislative or administrative requirement to do so. (Article 30, Paragraph 2).

\subsection{System weakness, compromises and unresolved questions}

The most serious weakness in the declared principle of simultaneous comparability of investments valued at historical cost and current value comes from the valuation provisions and relates to the fact that the Directive does not require comparative values to be disclosed in the case of revaluation of investments in accordance with Article 33, Paragraph 1, c of the Fourth Directive. (Examples of such revaluations are equity-valuation of shareholdings, index-valuation of land and buildings, etc.). (Refer, however, to the already mentioned Council Protocol to Article 46, Paragraph 3).

Aside from the essential principles of presentation, I would now like to explain the IAD harmonization principle of "Flexibility with Comparability". While doing this I will point out the important areas of compromise found within the Directive since these will be - and I remind the reader of the revision clause in Article 71 - the probable discussion points of the future.

In this regard the following areas are important.

\subsubsection{Balance sheet}

The presentation in the balance sheet of debtors and creditors with respect to affiliated companies - which corresponds to the Fourth Directive - does not include uncertain liabilities in the form of provisions, and therefore also does not include technical provisions, which for insurance undertakings form the overwhelming majority of long-term debt.

By way of exception, assets and liabilities in the form of deposits which, in connection with affiliated companies - specially in the context of reinsurance -, will for the most part not be visible.

In the profit and loss account, the presentation of relationships to affiliated companies is anyhow restricted to the area of financial incomes and expenses.

Therefore the presentation of relationships to affiliated companies (so to speak corresponding to the consolidated accounts) are comparatively less stringent in the annual accounts of insurance companies than for other companies subject to the general accounting standards of the Fourth Directive.

\subsubsection{Profit and loss account}

Here the presentation principles are much more flexible, almost without exception. These have an impact on: 


\subsubsection{The division of business areas between direct and indirect insurance business}

The present practice in some Member States of a division (i.e., disclosure in separate accounts?) between direct and indirect insurance business is not provided for, in principle, in either the area of the balance sheet or the profit and loss account of the IAD. (The areas of "Life assurance business" and "Non-life insurance business" are composed principally, of - respectively - direct business and ceded business). A separate presentation of either direct or indirect business would arise only in the exceptional case that in one or both classes of insurance (life and non-life) only direct or indirect business was written.

That means that an insurer carrying out Property and Casualty business, as well as indirect (Life) reinsurance business would have to prepare a separate Life-assurance technical account for its Life-reinsurance business. All of this makes things more complicated for active reinsurers.

As an exception to this principle, Member States could permit or require professional reinsurers and undertakings underwriting direct non-life insurance and also (life) reinsurance to use the technical account for non-life insurance business for all their business. A complete disclosure of the technical insurance components of the account would have to be shown in the notes on the accounts. Additionally, the Directive shows flexibility in how it deals with the division of profit and loss accounts into a technical and non-technical component which has been common in many Member States. As a basic principle, as already mentioned, in Life-assurance (and health insurance underwritten according to the technical principles of Life-assurance) income and expenditure should be included in the Life-assurance technical account. On the other hand, the income and expenditure with respect to investments should be included by non-life insurers in the non-technical account. A Member state option enables investment return to be transferred from one part of the profit and loss account to another. In the interest of consistency of consolidated financial statements, the Member states can permit or require that all original income and expenses of investments be shown in the non-technical account (with allocation of "technical" income to the technical account).

The treatment of change to the equalization provision which is in the $\mathrm{EC}$, as known, only prescribed for credit insurance and in other areas not coordinated seems, to me, like a second-best solution.

The Directive provides for special disclosure of the amount of change, insofar as the equalization reserve is permitted to be setup as a technical reserve in a Member State's national law. In this way the technical results are comparable, despite the lack of harmonization with regard to this special provision.

\subsubsection{Treatment of ceded reinsurance}

Whether to use the gross or net principle for reinsurance ceded is another basic question when discussing disclosure in financial statements of insurance companies.

With the gross principle, the result of the cedent is given in gross terms. The proportion of the components of this result assumed by the reinsurer are to be reported as separate items or shown as deductions from the gross amount. Under the latter method, the net amount shall be reported as a main heading under the pure net principle; the results shall be disclosed only after ceded business has been deducted. 
The Directive now provides - for both life and general business - a mixed set of accounting rules where, following the principle of materiality, the most important components of the ceded reinsurance must be specially disclosed.

Gross presentation is prescribed for:

- earned premiums

- claims incurred

- operating expenses

and additionally, in the case of life assurance, for

- change in the life assurance provision.

For the remaining technical income and expense items, the Directive prescribes a net treatment.

\subsubsection{Methods of periodical revenue apportionment}

The profit and loss account treatment of amounts received and paid (premiums, policyholders benefits, operating costs) corresponding to "technical provisions" (underwriting funds and provisions) is typically based on two methods under which the receipts and payments are taken without apportionment to the profit and loss account : (literally) the "turnover" method and "balanced turnover" method. Under the first method, revenue apportionment is affected by taking the opening and closing balances of the provisions at the beginning and end of the year and under the second method by taking only the net change in the provisions to the profit and loss account.

These contrast with the earnings method on which the standard layout in the Fourth EC Directive (and for example $\S 275$ ["Accounting for movements in provisions"] of the German Commercial Code) is based. Under this layout only figures affecting net earnings are taken as income and expenses to the profit and loss account (with separate disclosure of run-off-results).

The international treatment of receipts and payments corresponding to technical provisions is based exclusively on either the turnover method (for example, in France) or - in the vast majority of cases, I believe - on the balanced turnover method which the IAD also uses. A common feature of both these methods of presentation which dictate insurance practice is that they deliberately do not show income from the run-off of provisions separately but set it off against the relevant expense heading (usually claims incurred). Apart from the uniformity of method, this treatment has the advantage of clarity and conciseness in the presentation of claims incurred as the most important expense component in the technical account.

Alternatively, although in my opinion under the false label of irregular results, the IAD requires an explanation in the notes on the accounts of profits and losses arising out of the development of the claims provision, broken down by category and amount. This gives rise to a run-off result which, in my view, does not have an "extraordinary" character in the sense of Article 29 of the Fourth Directive. In insurance undertakings this result can only theoretically be regarded as extraordinary since such results are to be expected and therefore do not affect the comparability between undertakings. The carrying over of the requirement for the separate presentation of extraordinary amounts, in the sense of Article 29 of the Fourth Directive, is therefore questionable. 


\subsubsection{Functional reporting of operating expenses}

With respect to the analysis of operating expenses by functional area, the IAD has obviously decided (in favour of treatment as investment expenses) the question of whether depreciation of land and buildings used by the company itself should be treated under investment expenses or allocated according to functional areas.

Still unclear is :

Whether operating expenses also encompass expenses with respect to the services provided for affiliated companies such as insurance brokerage, asset management and claims settlement; and which therefore are not part of the company's own portfolio? (In my opinion, no). Does the possibility or the obligation exist to include a proportion of general operating expenses in the non-technical account?

The IAD has not clearly expressed by which principles costs relating to functionally defined areas such as business acquisition, claims settlement and asset management are to be divided. An arbitrary division of costs should not be allowed, in any case, since this contradicts the general principle of "true and fair view" which is expressed in the Fourth Directive and which, according to Article 1 of IAD, also applies to insurance undertakings. As far as a direct allocation of costs according to their source is not possible, then they should be allocated according to effect (the allocation criterion being determined objectively).

\subsubsection{Breakdown of insurance technical components of the result}

At this time it is common in many Member States to have a division (breakdown) of insurance technical results according to the individual classes (categories) of business.

The EC Directive has found a compromise here also, this time taking account of the overriding principle of materiality.

There is a duty to give information in the notes on the accounts (for specific categories of direct insurance business) about the main components of the technical insurance result premiums, claims incurred, costs and the "reinsurance balance". And indeed, the gross amounts of premiums, claim payments and costs basis must also be disclosed. This means that there will be for many Member States a heightened level of segmented reporting. This is very important for the evaluation of an insurance undertaking which is very dependent on the knowledge of its structure.

Of dubious significance in this context is the "reinsurance account". However, this balance may be determined by the result from ceded reinsurance, as opposed to other partial results in the profit and loss account and cannot be seen as a sign of whether reinsurance was actually profitable or not. The problematic nature of this provision is moreover the reason why the ceded reinsurance section in the Directive proved to be so controversial.

Nevertheless on the whole, one has to give good marks for the IAD'S principle of "Harmonization through Comparability". The IAD will probably not be, however, the last stage in international harmonization of insurance accounts. The process will most definitely go on. After all, there is still the revision clause in Article 71 ! 